Maya-Alvarado, B., Calva-Benítez, L.G., GranjaFernández, R., Pérez-López, J., \& López-Pérez, A. (2021). Feeding habits of Holothuria (Stauropora) fuscocinerea (Echinodermata: Holothuroidea) in a Mexican Pacific reef. Revista de Biología Tropical, 69(S1), 66-79. DOI 10.15517/rbt.v69iSuppl.1.46328

DOI 10.15517/rbt.v69iSuppl.1.46328

\title{
Feeding habits of Holothuria (Stauropora) fuscocinerea (Echinodermata: Holothuroidea) in a Mexican Pacific reef
}

\author{
Brenda Maya-Alvarado ${ }^{1,2}$ \\ Laura Georgina Calva-Benítez ${ }^{2}$ \\ Rebeca Granja-Fernández ${ }^{3}$ \\ Jessica Pérez-López ${ }^{2}$ \\ Andrés López-Pérez ${ }^{2 *}$
}

1. Programa de Maestría en Ciencias en Biosistemática y Manejo de Recursos Naturales y Agrícolas, Centro Universitario de Ciencias Biológicas y Agropecuarias, Universidad de Guadalajara, Av. Ing. Ramón Padilla Sánchez, Zapopan, Jalisco, México; brenda.maya971@alumnos.udg.mx

2. Laboratorio de Ecosistemas Costeros. Departamento de Hidrobiología, Universidad Autónoma Metropolitana Unidad Iztapalapa, Av. San Rafael Atlixco, Col. Vicentina, Iztapalapa, Ciudad de México, México; cblg@xanum.uam.mx, je_si13@hotmail.com, alopez@xanum.uam.mx (*Correspondence).

3. Laboratorio de Ecología Marina. Centro Universitario de la Costa, Universidad de Guadalajara, Av. Universidad, Puerto Vallarta, Jalisco, México; beckygranja@gmail.com

$$
\text { Received 01-VI-2020. Corrected 10-IX-2020. Accepted 07-X-2020. }
$$

\begin{abstract}
Introduction: The importance of holothuroids in marine ecosystems is related to their feeding activities, which have been little studied in the eastern Pacific. Objective: To describe the feeding habits of the sea cucumber Holothuria (Stauropora) fuscocinerea and their bioturbation potential in La Entrega reef, México. Methods: The population size of $H$. (Stauropora) fuscocinerea was determined by means of four $20 \times 4 \mathrm{~m}\left(320 \mathrm{~m}^{2}\right)$ band transects, while the available sediment for the sea cucumbers and their feces were characterized in three stations (A-C) via granulometry and quantification of organic carbon and organic matter. Excretion rate was determined every $4 \mathrm{hr}$ over a $24 \mathrm{hr}$ period and the relationship between sea cucumber length and biomass and the excretion rate evaluated. Results: According to non-parametric permutation, ordination and percentage similarity analyses, sea cucumber feces mostly comprised a large proportion of small grains compared to the available sediment, indicating that $H$. (Stauropora) fuscocinerea is selective on grain size. Preliminary bioturbation potential of the species may reach up to $8.71 \pm 0.17 \mathrm{~kg}$ day of sediment in the study area. Conclusion: The spatial distribution of $H$. (Stauropora) fuscocinerea in the study area is a product of its selective feeding activity, evidencing the preliminary importance of the species in the trophic dynamics of La Entrega reef.
\end{abstract}

Key words: selectivity; distribution; food; bioturbation; sea cucumber.

Holothuroids, commonly known as sea cucumbers, are conspicuous and abundant invertebrates that contribute largely to the biomass of marine ecosystems (Hendler, Miller, Pawson \& Kier, 1995). As a result of their feeding activity and diet, they can bioturbate large amounts of sediments every year (i.e. Crozier, 1918; Bonham \& Held, 1963; Bakus, 1973; Uthicke, 1999; Purcell, Conand, Uthicke \& Byrne, 2016), contributing to important 
chemical and physical processes on the seafloor, and promoting the continuous mixing of the sediment particles (Thayer, 1983). Sea cucumbers actively participate in the recycling of nutrients and organic matter within marine ecosystems (Bakus, 1973; Calva-Benítez, 2002), including coral reefs (Goldberg, 2013; Sheppard, Davy, Pilling \& Graham, 2017).

Despite being conspicuous and abundant in coral reefs around the world (Sheppard et al., 2017), the study of their feeding habits and their importance in sediment bioturbation in tropical reefs has focused mostly on holothuroids from the Indo-Pacific (Yang et al., 2005; Bucol, Cadivida \& Wagey, 2018; Rioja, Palomar-Abesamis \& Juinio-Meñez, 2020). Those studies have highlighted the selective nature of the feeding habits of holothuroids, as well as their capacity to remove large amounts of sediment and the wide spatial and temporal variation that exists among species (Trefz, 1956; Glynn, 1965; Bakus, 1968, 1973; Uthicke, 1999; Mezali \& Soualili, 2013; Belbachir, Mezali \& Soualili, 2014).

Holothuria (Stauropora) fuscocinerea is among the most common and widely distributed holothuroid in the Indo and eastern tropical Pacific (Purcell, Samyn \& Conand, 2012; Solís-Marín et al., 2013; Cortés et al., 2017). However, little is known about its biology, abundance and distribution, feeding habits and generally, the role that this species plays in the ecosystem. To date, the only study of the species in the region is limited to its annual reproductive periodicity on the coast of Oaxaca, México (Benítez-Villalobos, AvilaPoveda, \& Gutiérrez-Méndez, 2013). In the Mexican Pacific and the Gulf of California, sea cucumbers such as Isostichopus fuscus (Herrero-Pérezrul \& Chávez, 2005) and Holothuria (Halodeima) inornata are regularly exploited commercially and are currently under the protection of Mexican laws (SEMARNAT, 2019). On the other hand, H. (Stauropora) fuscocinerea, is of commercial importance in China, Malaysia and the Philippines (Purcell et al., 2012), but lacks protection status in México. Due to the paucity of information about the species, its commercial importance and the relevance of holothuroids for bioturbation in reef ecosystems, this study aims to: a) determine the feeding habits of $H$. (Stauropora) fuscocinerea in a tropical reef in the Mexican Pacific, and b) address their bioturbation potential. With this information, inferences can be made in terms of its small-scale distribution, along with its feeding selectivity and its contribution to sediment bioturbation in a typical reef system of the eastern tropical Pacific.

\section{MATERIALS AND METHODS}

Study area: The study was carried out at La Entrega bay (1544'34" N \& 96 $\left.07^{\circ} 35^{\prime \prime} \mathrm{W}\right)$, located in southwest end of the Gulf of Tehuantepec, Oaxaca, México (Fig. 1). La Entrega is a small $\left(0.1 \mathrm{~km}^{2}\right)$ embayment located on the west side of Santa Cruz bay. The seafloor of La Entrega consists of marine carbonate sediment mixed with siliciclastic material derived from the basaltic highlands of the Copalita river basin (Estrada-Vargas, 2008). The center of La Entrega is largely covered by an approximately 4.3 ha reef framework that follows a southwest-northeast direction and reaches 12 $m$ in depth (Glynn \& Leyte-Morales, 1997). The coral community is composed by 11 coral species, live coral cover comprises $76.58 \%$ of the reef area, while the framework is built mainly by Pocillopora spp. species (> $95 \%$ ), followed by Pavona spp. and Porites panamensis (López-Pérez \& López-García, 2008; Cabral-Tena et al., 2020).

The southwestern portion of the reef corresponds to the reef flat (2-5 $\mathrm{m}$ in depth) and comprises most of the reef framework, while the fore reef comprises $\sim 30 \%$ of the area. While the former results of the interlocking of Pocillopora spp. colonies, the fore reef area is a transition zone where live coral cover is severely reduced $(\sim 70 \%)$ and branching Pocillopora spp. and the massive corals Pavona gigantea and Pavona varians coexist with the emerald coral $P$. panamensis, along with sparse patches of sand and dead corals 


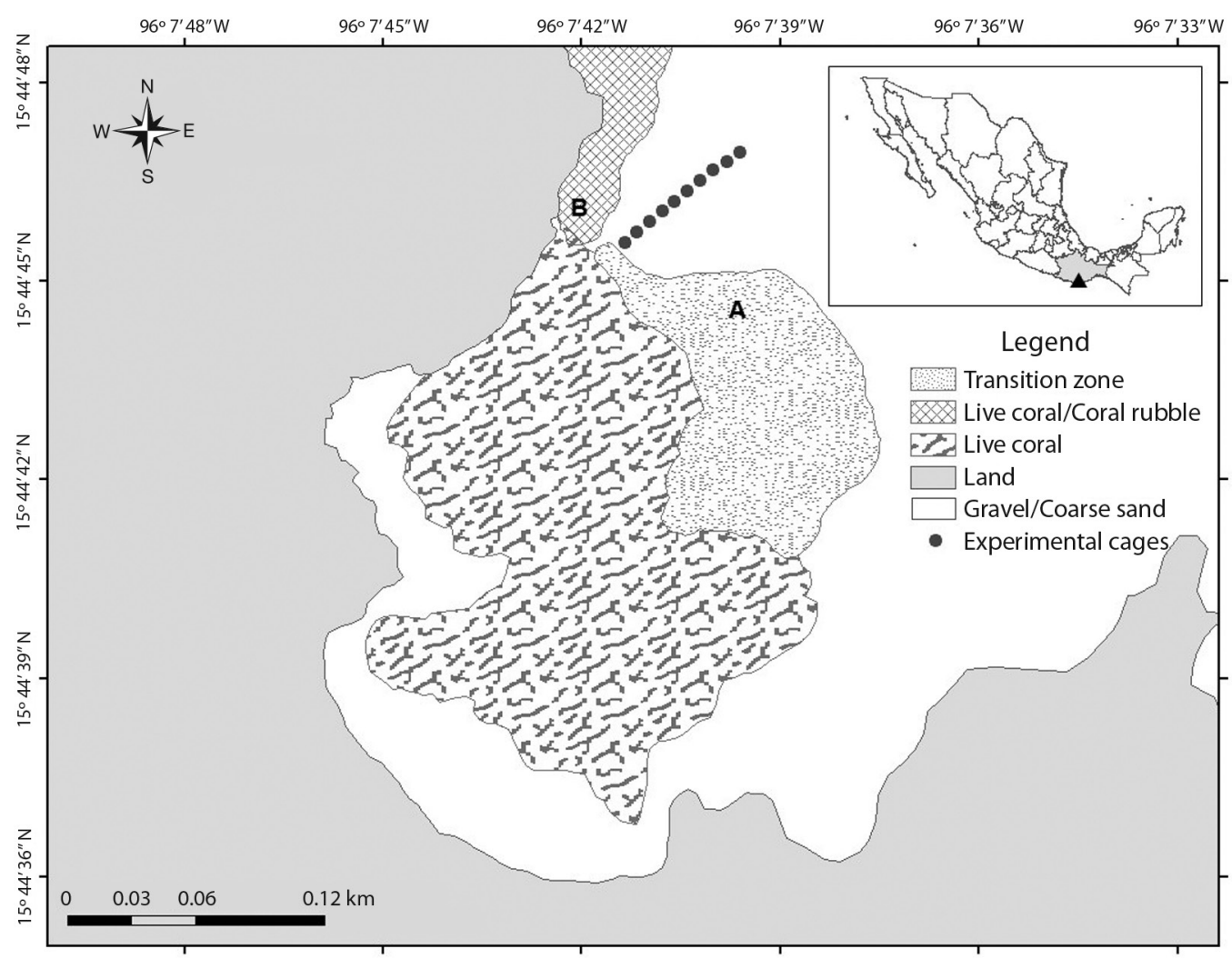

Fig. 1. Sampling stations (A, B, C [experimental cages]) and zoning of La Entrega reef, Mexican Pacific. See text for information regarding sampling stations.

(Glynn \& Leyte-Morales, 1997; López-Pérez \& Hernández-Ballesteros, 2004) (Fig. 1).

La Entrega reef is habitat of several marine invertebrates, including echinoderms (LópezPérez et al., 2019). Among the echinoderm species, the sea cucumber H. (Stauropora) fuscocinerea is mainly distributed in the fore reef transition zone between the reef flat and the sandy area (transition zone A), as well as in the live coral-coral rubble (zone B) but absent in the sand area (C) (Fig. 1). Finally, La Entrega has been subjected to intense touristic activity and recurrent dredging at least yearly since the early 1990's, which has resulted in high quantities of organic matter, therefore diminishing the health of the system (López-Pérez \& Hernández-Ballesteros, 2004; Díaz-Díaz, 2017).
Fieldwork: The population density of $H$. (Stauropora) fuscocinerea (Fig. 2A) in La Entrega was determined during SCUBA diving visual censuses, using four $20 \times 4 \mathrm{~m}$ (320 $\mathrm{m}^{2}$ ) belt transects. During January 2018, visual census was conducted at two stations parallel to the coastline, called A and B, at a depth of $10 \mathrm{~m}$ (Fig. 1).

The available sediment was collected in situ near the mouth and feces near the anus of 20 specimens of $H$. (Stauropora) fuscocinerea (Fig. 2A, 2B, 2C), randomly selected in each of the stations $A$ and $B$, in which coral sand (A) and coral debris (B) predominate (Fig. 1). The samples were collected manually with a plastic spoon, placed in individual 


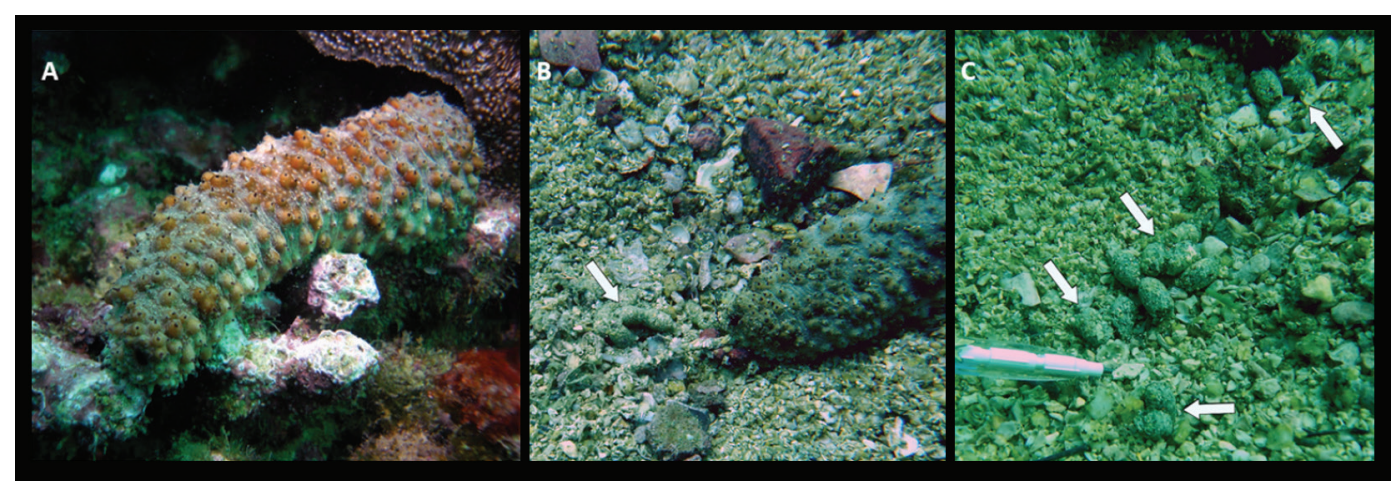

Fig. 2. A. Holothuria (Stauropora) fuscocinerea. B. Feces of Holothuria (Stauropora) fuscocinerea. C. Close-up feces.

sealable plastic bags, and stored frozen until subsequent processing.

Furthermore, individuals of $H$. (Stauropora) fuscocinerea were placed in individual enclosures (one individual per enclosure, ten enclosures) at station $\mathrm{C}$ in order to measure the rate of excretion of the cucumbers over a total period of $24 \mathrm{~h}$. These enclosures were constructed of wire rod and cloth mesh and were 1 $\mathrm{m}$ in diameter (Fig. 3); on the upper and lateral part, each enclosure was covered with the cloth mesh, while the lower part allowed H. (Stauropora) fuscocinerea to feed on the sediment. The enclosures were anchored to the bottom to prevent escape of the organisms. In each confinement, the feces of sea cucumbers were collected at $4 \mathrm{~h}$ intervals over a $24 \mathrm{~h}$ period $(\mathrm{T} 1=$ $21: 40 \mathrm{hr} ; \mathrm{T} 2=1: 40 \mathrm{hr} ; \mathrm{T} 3=5: 40 \mathrm{hr} ; \mathrm{T} 4=9: 40$ $\mathrm{hr}, \mathrm{T} 5=13: 40 \mathrm{hr} ; \mathrm{T} 6=17: 40 \mathrm{hr} ; \mathrm{T} 7=21: 40$ $\mathrm{hr}$ ). In order to characterize the sediments from which the sea cucumbers were feeding in each enclosure, three sediment samples from each enclosure ( 3 x 10 enclosures, $\mathrm{N}=30$ ) were collected at the beginning (T1) of the experiment. The collected fecal and sediment samples were placed in individual sealable plastic bags and stored at low temperature $\left(\approx 4{ }^{\circ} \mathrm{C}\right)$ until subsequent analysis in the laboratory.

Finally, the length of the individuals that remained in the enclosures was measured with a metric tape (length/width) every $4 \mathrm{~h}$ and this parameter was related to the wet weight, which was obtained 90 seconds after removing the animals from the water (Uthicke, 1999) at the end of the experiment, using an Oahus CR2200 balance ( $\pm 1 \mathrm{~g}$ precision).

Laboratory work: Samples (sediment and feces) were thawed, placed on aluminum trays and dried at room temperature until dry. Sediment texture analysis was then performed and the content of organic carbon (O.C.) and organic matter (O.M.) determined.

Granulometric analysis was performed using the dry sieving technique. The dry weights of the following fractions were determined: granules $(2000 \mu \mathrm{m})$, very coarse sand $(1000 \mu \mathrm{m})$, coarse sand $(500 \mu \mathrm{m})$, medium sand $(250 \mu \mathrm{m})$, fine sand $(125 \mu \mathrm{m})$, very fine sand $(62.5 \mu \mathrm{m})$, and silt $(28 \mu \mathrm{m})$.

The O.C. content was determined using the technique proposed by Gaudette, Flight, Toner \& Folger (1974), which consists of drying the sediments at room temperature and then sieving them to remove gravel through a $62.5 \mu \mathrm{m}$ mesh $(0.500 \mathrm{~g}$ of it is treated $)$. The organic matter is then oxidized, and the excess potassium dichromate titrated with ferrous sulfate. The samples were analyzed in duplicates and two blanks processed in the same way as controls. With this technique, the presence of carbonates does not produce interference, has an accuracy of $\pm 0.25 \%$, and yields solid results (ShohamFrider et al., 2020). In addition, the technique has been successfully used to evaluate the ability of holothuroids to remove organic matter 


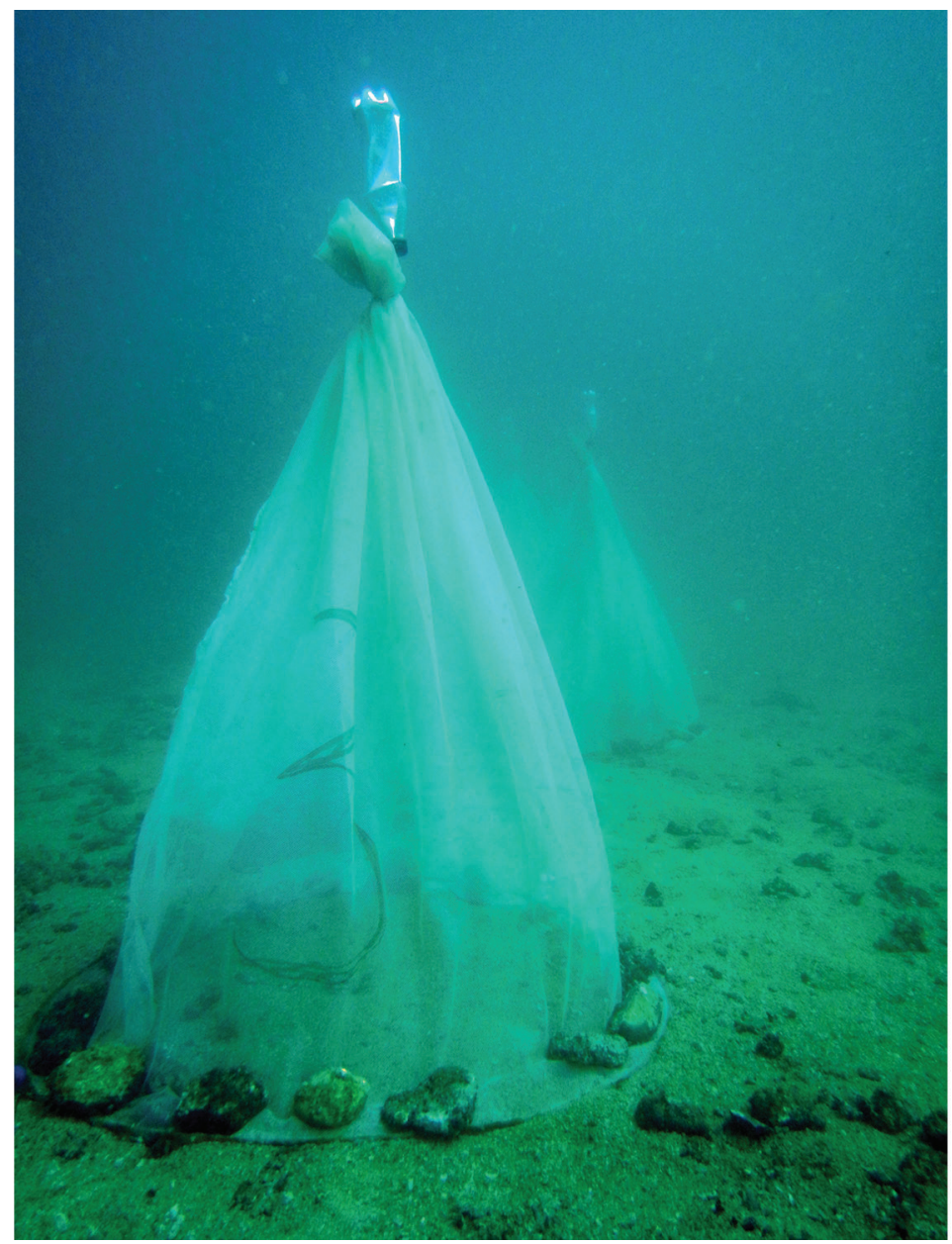

Fig. 3. Experimental cages used in the field study during January 2018. La Entrega reef, Mexican Pacific.

in eutrophic and hypereutrophic environments (Emiroglu \& Günay, 2007).

Finally, the organic matter (O.M.) content was estimated as the product of the O.C. using the van Bemmelen factor (1.72; Grybos, Davranche, Gruau \& Petitjean, 2007) who assume that, on average, $58 \%$ of the O.M. is composed of carbon.

Data analysis: In order to graphically represent the relationships between sediment samples and feces from the three stations (A, B, C), the database (size fractions + O.C. + O.M.) was analyzed using a principal components analysis (PCA) from a normalized matrix.
Since PCA is an ordination technique and does not have an associated statistical hypothesis, statistical differences between sediment and feces were evaluated using a permutationsbased unbalanced factor analysis of variance (PERMANOVA). The stations (A, B, C) were considered as a fixed factor (type I model). The PERMANOVA was constructed from a Euclidean distance matrix following the criteria of Anderson, Gorley \& Clarke (2008). Nonparametric analysis was performed since data did not meet the assumptions of normality and homoscedasticity.

In order to explore the degree of selectivity of the individuals during the feeding process, a 
percentage similarity test (SIMPER) was carried out with the aim of estimating the similarity/dissimilarity of the available sediment and feces among the sampling stations, and also to identify which variables contributed the most to explaining these compositional differences.

Simple linear regression models were performed to establish a relationship between the length of the individuals and the biomass, as well as between the length and dry weight of the feces. On the other hand, in sampling station $\mathrm{C}$, it was evaluated if there were differences in the excretion rate over time using a one-way non-parametric analysis of variance (ANOVA) with fixed effects. Finally, the preliminary bioturbation potential of the species in the study area was estimated considering population density, the area inhabited, and the excretion rate by $H$. (Stauropora) fuscocinerea in La Entrega.

PCA, PERMANOVA and SIMPER were performed using the PRIMER $6+$ PERMANOVA software (Anderson et al., 2008). The regression models and the non-parametric ANOVA were carried out in the STATISTICA v.7.1 software (Statsoft, 2020). All statistical tests used $\alpha=0.05$.

\section{RESULTS}

Density and individual size: Holothuria (Stauropora) fuscocinerea distribute differentially across space in La Entrega reef. The species is absent from the Pocillopora spp. interlocking patch and the sandy area $(0.0 \mathrm{ind} /$ $\mathrm{m}^{2}$ ), but in the transition and live coral/coral rubble area may reach an average of $0.27 \mathrm{ind} /$ $\mathrm{m}^{2}$ ( \pm 0.02$)$. Additionally, individuals had an average length of $24.60 \mathrm{~cm}( \pm 5.77)$ and an average weight of $142 \mathrm{~g}( \pm 41.64)$.

Sediment and feces composition: Sediment and feces composition of $H$. (Stauropora) fuscocinerea for each sampling station are presented in Table 1, and PCA ordination summarize the trends among sediment and feces, but also among stations.
From sampling station $\mathrm{A}$ to $\mathrm{C}$, there is an increase in large size fractions of sediment (granule-very coarse sand), while the opposite trend is recorded for coarse sand to fine sand fractions, including organic carbon and matter; meanwhile, for very fine sand and silt fractions, large values were recorded in station $\mathrm{B}$, followed by station A and C, respectively (Table 1). The observed trend in sediment composition (granulometry, C.O., and M.O.) across space is supported by permutational analysis of vari-

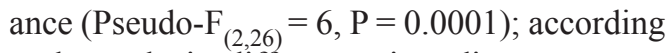
to the analysis, differences in sediment composition occurred among station $\mathrm{A}$ and $\mathrm{C}$ (Pseudo$\mathrm{t}=2.81, \mathrm{P}=0.0008$ ), and $\mathrm{C}$ and $\mathrm{B}$ (Pseudo- $\mathrm{t}$ $=3.42, \mathrm{P}=0.0001)$, while sediment composition between station A and B is relatively homogeneous. In station $\mathrm{C}$, the sediments are characterized by granules, very coarse sands and coarse sands with O.C. content of 0.33 $\%$ and O.M. content of $0.56 \%$ (Table 1). In stations $\mathrm{A}$ and $\mathrm{B}$, in addition to their O.C. and O.M. characteristics, the sediments are highly heterogeneous among samples within the same station which translates in the wide overlap in the characteristics between stations $\mathrm{A}$ and $\mathrm{B}$ (Pseudo-t = 1.52, $\mathrm{P}=$ 0.07; Table 1, Fig. 4).

Regarding feces, for granules and silt, station B had larger values than station A, followed by station $C$; for very coarse sand and coarse sand, station $\mathrm{C}$ showed larger values than station B, followed by station A; finally, for medium sand and fine sand fractions, feces in station A showed larger values than stations $\mathrm{C}$ and $\mathrm{B}$, respectively (Table 1). Feces composition show a relative homogeneity among samples from the same station (Fig. 4), and the overlap between stations is relatively smaller, suggesting there is less variation among feces than among the sediment available to sea cucumbers in each sampling station. In general, the feces from station A are characterized by their content of medium sand, coarse sand, fine sand and very coarse sand along with moderate values of O.C. $(0.70 \%)$ and O.M. (1.21 $\%)$ (Table 1). The feces from station B are characterized by very coarse sand, granules, coarse sand, medium sand, and relatively high 


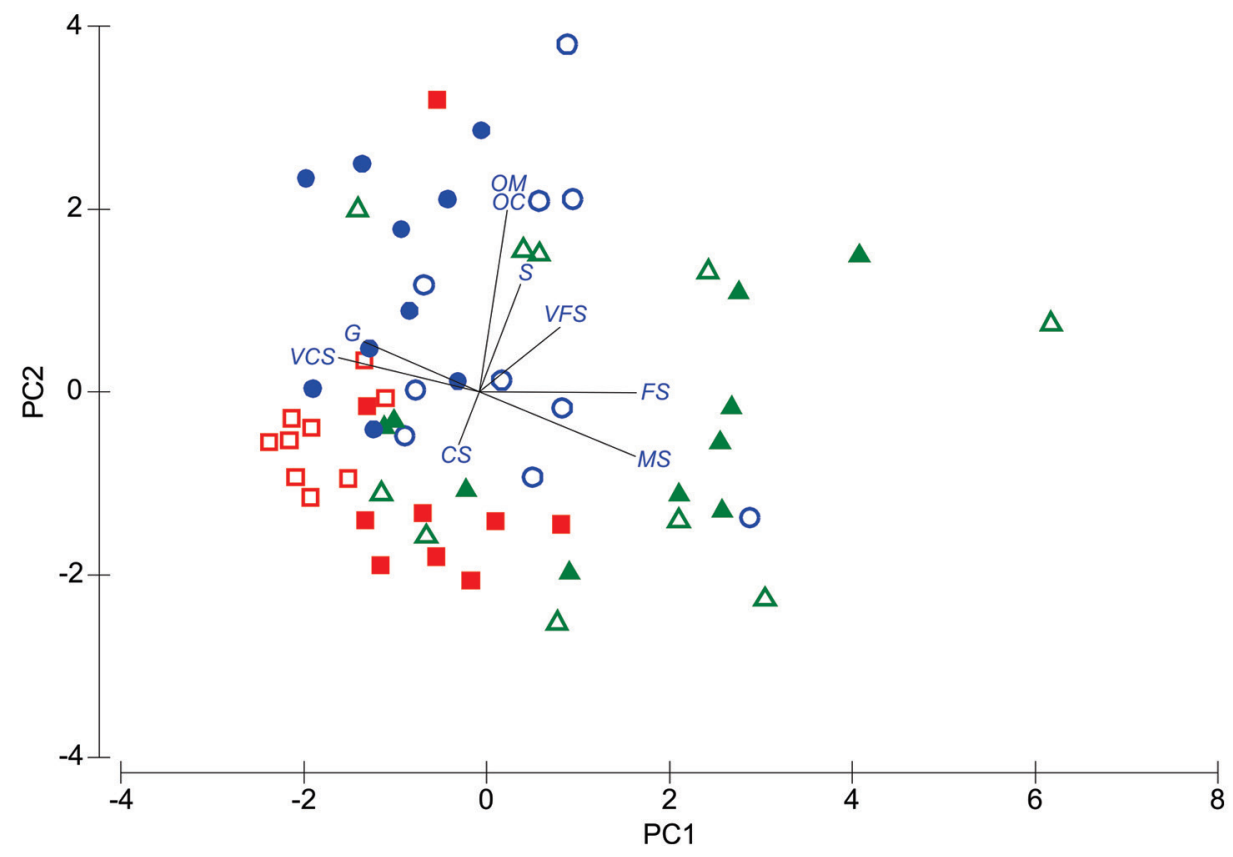

Fig. 4. Ordination (Principal Components Analysis) of sediment (open figures) and feces (filled figures) composition across space in La Entrega reef, Mexican Pacific. Sampling stations, A = green, B = blue, C = red. See Figure 1 for spatial location of sampling stations. Vector longitude $=$ relative importance of the variable in the ordination. $\mathrm{OM}=$ Organic matter, $\mathrm{OC}=$ Organic carbon, $\mathrm{G}=$ Granule, $\mathrm{VCS}=$ Very coarse sand, $\mathrm{CS}=$ Coarse sand, $\mathrm{MS}=$ Medium sand, $\mathrm{S}=$ Sand, $\mathrm{FS}=\mathrm{Fine}$ sand, VFS $=$ Very fine sand, $S=$ Silt.

TABLE 1

Percentage of size fractions, organic carbon and organic matter of available sediments and feces of Holothuria (Stauropora) fuscocinerea in La Entrega reef, Mexican Pacific

\begin{tabular}{lcccccc}
\multicolumn{1}{c}{ Size fraction } & \multicolumn{3}{c}{ Sediment } & F & Feces \\
Granule & $\mathrm{A}$ & $\mathrm{B}$ & $\mathrm{C}$ & $\mathrm{A}$ & $\mathrm{B}$ & $\mathrm{C}$ \\
Very coarse sand & $12.81 \pm 9.75$ & $23.91 \pm 7.82$ & $36.28 \pm 7.26$ & $5.84 \pm 8.78$ & $26.62 \pm 15.44$ & $3.05 \pm 1.59$ \\
Coarse sand & $34.66 \pm 10.45$ & $29.76 \pm 4.21$ & $26.58 \pm 6.05$ & $23.45 \pm 11.82$ & $23.55 \pm 6.94$ & $29.52 \pm 3.12$ \\
Medium sand & $28.52 \pm 14.86$ & $18.35 \pm 9.43$ & $8.44 \pm 3.95$ & $36.55 \pm 14.85$ & $12.05 \pm 4.03$ & $22.2 \pm 8.18$ \\
Fine sand & $6.2 \pm 6.34$ & $4.65 \pm 2.23$ & $1 \pm 0.5$ & $19.68 \pm 12.68$ & $5.2 \pm 2.8$ & $6.23 \pm 4.28$ \\
Very fine sand & $0.57 \pm 0.6$ & $1.13 \pm 0.42$ & $0.01 \pm 0.02$ & $3.51 \pm 2.7$ & $3.04 \pm 1.47$ & $3.97 \pm 3.3$ \\
Silt & $0.16 \pm 0.19$ & $0.59 \pm 0.47$ & $0.04 \pm 0.11$ & $0.91 \pm 1.45$ & $1.44 \pm 1$ & $0.0 \pm 0.0$ \\
Organic carbon & $0.73 \pm 0.71$ & $0.63 \pm 0.42$ & $0.33 \pm 0.19$ & $0.70 \pm 0.37$ & $1.04 \pm 0.42$ & $0.51 \pm 0.5$ \\
Organic matter & $1.26 \pm 1.22$ & $1.09 \pm 0.73$ & $0.56 \pm 0.33$ & $1.21 \pm 0.65$ & $1.8 \pm 0.73$ & $0.87 \pm 0.86$ \\
\hline
\end{tabular}

Values represents mean \pm standard deviation. See Fig. 1 for location of sampling stations (A, B, C).

O.C. (1.04 \%) and O.M. (1.8 \%) values, while those at station $\mathrm{C}$ are dominated by very coarse sand, coarse sand, medium sand, and relatively low O.C. $(0.51 \%)$ and O.M. $(0.87 \%)$ values (Table 1, Fig. 4).
Size selection of sediment particles: The PERMANOVA indicated that there were differences between sediment and feces composition in stations $\mathrm{B}$ (Pseudo- $\mathrm{t}=1.90, \mathrm{P}=0.01)$ and $\mathrm{C}$ (Pseudo- $\mathrm{t}=2.74, \mathrm{P}=0.0007$ ), but not between 
TABLE 2

Summary of SIMPER results for feeding habits of Holothuria (Stauropora) fuscocinerea in La Entrega reef, Mexican Pacific

\begin{tabular}{|c|c|c|c|}
\hline Variable & Av. Sediment & Av. Feces & Contribution $\%$ \\
\hline \multicolumn{4}{|c|}{$\begin{array}{l}\text { Station A } \\
\text { Average squared distance }=2.05 \times 10^{8}\end{array}$} \\
\hline O.M. & $9.8 \times 10^{-3}$ & $1.1 \times 10^{-4}$ & 91.4 \\
\hline \multicolumn{4}{|c|}{$\begin{array}{l}\text { Station B } \\
\text { Average squared distance }=1.51 \times 10^{8}\end{array}$} \\
\hline O.M. & $6.42 \times 10^{-3}$ & $1.2 \times 10^{-4}$ & 94.59 \\
\hline \multicolumn{4}{|c|}{$\begin{array}{l}\text { Station C } \\
\text { Average squared distance }=8.73 \times 10^{8}\end{array}$} \\
\hline Medium sand & $3.16 \times 10^{-14}$ & $1.12 \times 10^{-14}$ & 18.27 \\
\hline O.C. & $2.56 \times 10^{-14}$ & $2.32 \times 10^{-14}$ & 15.93 \\
\hline O.M. & $3.02 \times 10^{-14}$ & $2.42 \times 10^{-14}$ & 15.51 \\
\hline Very fine sand & $8.15 \times 10^{-13}$ & $1.88 \times 10^{-14}$ & 14.38 \\
\hline Fine sand & $1.15 \times 10^{-14}$ & $1.77 \times 10^{-14}$ & 14.30 \\
\hline Granule & $1.78 \times 10^{-14}$ & $1.58 \times 10^{-14}$ & 9.23 \\
\hline Very coarse sand & $1.77 \times 10^{-14}$ & $7.65 \times 10^{-13}$ & 5.43 \\
\hline
\end{tabular}

Average contribution (Av. \%) of discriminating sedimentary characteristics in each sediment availability and feces group, their contribution (\%) to the dissimilarity between groups, and cumulative total $(\%)$ of contributions $(90 \%$ cut-off). O.C. $=$ organic carbon; O.M. = organic matter.

the available sediments and feces from station A (Pseudo- $\mathrm{t}=0.86, \mathrm{P}=0.54)$. The statistical differences observed between sediment and feces at each station are clearly depicted by the spatial distance between the open and filled figures in the PCA ordination in stations B and C (Fig. 4).

The SIMPER analysis between the characteristics of the available sediment and feces showed that the greatest differences in the composition occurred in station $\mathrm{C}$, followed by station A, and finally station B (Table 2). The difference between the sediment characteristics of the feces and those of the available sediment had a relationship presenting the lowest percentage of large sand grains (granules, very coarse, coarse and medium sand), the highest percentage of small grains (fine and very fine sands, and silts), a higher percentage of O.C. with respect to the available sediment in stations $\mathrm{A}$ and $\mathrm{B}$, and a lower percentage of O.M. and O.C. compared to that of the available sediment in station $\mathrm{C}$ (Table 2).
Sediment bioturbation: According to data, H. (Stauropora) fuscocinerea bioturbated $0.1 \mathrm{~g} \mathrm{ind}^{-1} \mathrm{hr}^{-1}( \pm 0.15)$; across time, KruskalWallis test evidenced differences in bioturbation $\left(\mathrm{H}_{(5,57)}=19.73, \mathrm{P}=0.001\right)$ between $\mathrm{T} 1$ $\left(0.01 \mathrm{~g}\right.$ ind $\left.^{-1} \mathrm{hr}^{-1} \pm 0.04\right)$ and T2 $\left(0.0 \mathrm{~g} \mathrm{ind}^{-1} \mathrm{hr}^{-1}\right.$ $\pm 0.0)$, regarding T4 $\left(0.21 \mathrm{~g} \mathrm{ind}^{-1} \mathrm{hr}^{-1} \pm 0.21\right)$ (T1 vs $\mathrm{T} 4, \mathrm{H}=3.09, \mathrm{P}=0.03 ; \mathrm{T} 2$ vs $\mathrm{T} 4, \mathrm{H}=$ $3.29, \mathrm{P}=0.01$ ).

The simple regression model showed no relationship between the sea cucumber length and biomass $\left(\mathrm{R}^{2}=0.09, \mathrm{~N}=10, \mathrm{P}>0.05\right)$, nor between the length and weight of feces $\left(\mathrm{R}^{2}=\right.$ $0.08, \mathrm{~N}=10, \mathrm{P}>0.05$ ); therefore, available data did not support that the amount of sediment that $H$. (Stauropora) fuscocinerea bioturbates through feeding activity varies according to the size of the organism.

Finally, considering the population density of the species obtained through visual censuses

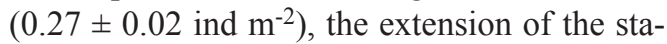
tions A (10 $211 \mathrm{~m} 2)$ and B $\left(4200 \mathrm{~m}^{2}\right)$, and the average bioturbation rate per sea cucumber per 
day $\left(2.24 \pm 3.71 \mathrm{gr}\right.$ ind $^{-1}$ day $)$, it is estimated that $8.71 \pm 0.17 \mathrm{~kg}$ of sediment in a single day was bioturbated during the feeding activity of the H. (Stauropora) fuscocinerea population in the study area.

\section{DISCUSSION}

Studies addressing sediment composition in eastern Pacific reef systems are scarce (Estrada-Vargas, 2008; Granja-Fernández \& López-Pérez, 2008; Díaz-Díaz, 2017), while the effect of sediment characteristics in the distribution of organisms at small spatial scales has been exclusively studied in asteroids (LunaSalguero \& Reyes-Bonilla, 2010) and molluscs (Barrientos-Lujan et al., 2019). In the same way, the results of the present research indicate that the spatial distribution of the sea cucumber H. (Stauropora) fuscocinerea in La Entrega reef is closely tied to sediment size distribution and the amount of organic material associated with very fine sand and silt fractions. According to data, the species selectively feeds on sand in the transition zone, collecting sediment and particles from the seabed with its mouth tentacles. As a result of these feeding habits, the species is generally found where granules, very coarse sands or coarse sands represent less than $30 \%$ of the sediment, and where the presence of silts and very fine sands range from 0 to $4 \%$. Moreover, it is generally found where the average O.C. content ranges 0.707-1.02\% and O.M. averages 1.22-1.75\%. Consequently, $H$. (Stauropora) fuscocinerea is distributed in the transition area between the reef patch and the adjacent sand (i.e. stations A and B), while its presence is null on corals or in sites where coarse and very coarse sands are the main components (i.e. station C). This agrees with the results of Bakus (1973), who states that detritivores holothuroids predominate in fine sediments, Yamanouchi (1939) who observed that the population density of the sea cucumber Bohadschia vitiens was lower where live corals were abundant because there was a low presence of sand, and Massin \& Jangoux (1976) who indicated that Holothuria (Holothuria) tubulosa lives exclusively in sandy sediments and in the absence of a hard substrate. In summary, the results of the present and aforementioned studies indicate a close relationship between sedimentary characteristics and the distribution of holothuroids at small spatial scales. This distribution could not only be influenced by the proportion and size of the sediments, but also by their nutritional value.

In detritivores holothuroids, the relationship between sediment characteristics and the distribution of organisms is closely related to the selective feeding habits of the sea cucumbers (Massin \& Jangoux, 1976; Hammond, 1983; Uthicke, 1994). Results related to the spatial distribution of $H$. (Stauropora) fuscocinerea individuals within the reef, the large percentage of smaller sediment fractions (fine sands to silts) found in the feces compared to the sediment available in the environment (Table 1, Fig. 4) and the significant statistical differences between the composition of the feces and the available sediments, strongly supports the selective feeding habits of H. (Stauropora) fuscocinerea in the study area. According to both, the permutation analysis and SIMPER, the greatest difference between sediment and feces was found in station $C$, where there was a lesser order of magnitude with very coarse sands, fewer granules and medium sand. A higher percentage of fine and very fine sand in the feces of $H$. (Stauropora) fuscocinerea (Table 2), suggested selectivity of small size sediment fractions as observed in the Holothuria (Roweothuria) poli sea cucumber (40-200 $\mu \mathrm{m})$ (Mezali \& Soualili, 2013; Belbachir et al., 2014), as well as in Astichopus multifidus that feeds on fine-grained calcareous sediments $(250 \mu \mathrm{m})($ Glynn, 1965). The fine to very fine fractions found in $H$. (Stauropora) fuscocinerea feces, which were common in the sediments of stations A and B but scarce in the sediments of station $\mathrm{C}$, possess a high concentration of organic matter since the sorption capacity and the surface-volume ratio increases in fine fractions (Berthois, Crosnier \& Le Calvez, 1968; Poppe, Knebel, Mlodzinska, Hastings \& Seekins, 2000). It seems feasible to suggest that 
H. (Stauropora) fuscocinerea spatial distribution is related to the ability of the holothuroids to locate patches enriched with organic matter and to the efficiency of food assimilation, intestinal transit time, and the cost of rejecting particles in these organisms, known as "Optimal Food Theory" (Taghon, Self \& Jumars, 1978; Billet, Llewellyn \& Watson, 1988).

Through their activities of ingestion and excretion, holothuroids are known to be important recyclers of nutrients in reef systems by converting organic nutrients bound to sediments into inorganic nutrients dissolved in the water column (Uthicke, 1999), and further into biomass in upper trophic levels or as nutrients that increase primary productivity (Purcell et al., 2016). Although feces may be enrichened in nutrients through their transit in the sea cucumber gut (e.g. Massin, 1979; Hammond, 1983; Amon \& Herndl, 1991), most of the time when sediments pass through the intestines of holothuroids, the defecated sediments can be lower in nutrients than the ingested sediments, and thus these organisms act as sediment-cleaners (Longbottom, 1970; Mercier, Battaglene \& Hamel, 1999; Uthicke, 1999; Michio et al., 2003; Yuan et al., 2006; Zhou et al., 2006), and have been considered as a means of restricting or reversing the effects of pollution from aquaculture (Slater \& Carton, 2009). Emiroglu \& Günary (2007), for example, suggested that $H$. (Holothuria) tubulosa can eliminate biological pollution and improve water quality in eutrophic and hypereutrophic environments of the coastal regions. In this regard, heavily tourist visits to coastal reef areas such as La Entrega (FONATUR, 2008), where large amounts of organic matter have been recorded (Díaz-Díaz, 2017) may benefit from $H$. (Stauropora) fuscocinerea presence and feeding activity.

Holothuroids actively ingest sediments, but present varied feeding rates since they are capable of feeding either continuously (Yamanouchi, 1956; Bonham \& Held, 1963; Massin \& Jangoux, 1976; Hammond, 1982; Uthicke, 1994) or discontinuously within a 24 h cycle (Crozier, 1918; Bakus, 1968; Massin \& Jangoux, 1976). The feeding rates of holothuroids is related to light intensity, variations in temperature, and other environmental conditions such as water movement (Massin \& Jangoux, 1976; Uthicke, 1994). According to Massin and Jangoux (1976), H. (Holothuria) tubulosa is a continuous feeder that, in summer, increases its feeding activity at night and decreases it during the day, while juveniles of Holothuria (Metriatyla) scabra feed continuously (Mercier et al., 1999). In the present study, differences in the excretion rate in a $24 \mathrm{~h}$ cycle were recorded; according to data, larger excretion rates occurred early in the morning probably related to intense feeding activity during the night (Crozier, 1918; Bakus, 1968; Massin \& Jangoux, 1976), but also may have resulted from changes in feeding activity of the experimental organisms since they were relocated to experimental cages in areas where $H$. (Stauropora) fuscocinerea does not currently distribute. More data, nevertheless, are needed to accurately assess daily and seasonal feeding rates changes in the species.

Concurrently, while some authors (Crozier, 1918, Isostichopus badionotus; Ruiz, Ibáñez \& Cáceres, 2007, Athyonidium chilensis) observed a relationship between the total length of the holothuroids and the average weight of the full alimentary tract, such that the total length of the intestine increased with the size of this species, results in La Entrega indicated a lack of length-weight and weightexcretion rate relationships in H. (Stauropora) fuscocinerea individuals. Therefore, our results should be considered with caution since sea cucumber size is strongly subjected to changes in response to handling or its resting state (Ebert, 2021) and sample size may be insufficient to address meaningful relationships if any. Preliminary data, nevertheless, may give us insight on the bioturbation potential of $H$. (Stauropora) fuscocinerea in the studied area. If it is assumed that all H. (Stauropora) fuscocinerea individuals in La Entrega have similar sizes and weights, and hence feeding rates are homogeneous among individuals, H. (Stauropora) fuscocinerea population may have had the potential to bioturbate 8.71 
$\pm 0.17 \mathrm{~kg}$ day of sediment over $14411 \mathrm{~m}^{2}$ corresponding to the area where the species currently occurs in La Entrega reef. Preliminary bioturbation potential of $H$. (Stauropora) fuscocinerea addressed in the studied area is smaller than that reported for other species. Coulon and Jangoux (1993) obtained different values for the lower and upper part of the algal grasslands of Lacco Ameno (Italy), at 5.9 and $12.9 \mathrm{~kg}$ of dry sediment per year, respectively; while Uthicke (1999) showed that H. (Halodeima) atra removes up to $24.5 \mathrm{~kg}$ of sediment per year and Stichopus chloronotus removes $21.5 \mathrm{~kg}$ per year at Lizard Island (Great Barrier Reef). In order to establish meaningful comparison with other studies, strong empirical information regarding size-related bioturbation changes, size-frequency distribution of individuals, population size and their variation across time are mandatory. It should be noted that this study addressed the preliminary bioturbation potential of $H$. (Stauropora) fuscocinerea, while the importance of other abundant and widespread species such as Isostichopus fuscus and Holothuria (Halodeima) inornata remains unquantified. Addressing the bioturbation potential of sea cucumbers without doubt, it is of relevance for understanding the importance of the guild in the functioning of coastal systems, particularly in reef systems with high organic load such as those located on the eastern tropical Pacific.

Ethical statement: authors declare that they all agree with this publication and made significant contributions; that there is no conflict of interest of any kind; and that we followed all pertinent ethical and legal procedures and requirements. All financial sources are fully and clearly stated in the acknowledgements section. A signed document has been filed in the journal archives.

\section{ACKNOWLEDGMENTS}

We are thankful to Buceo Huatulco for logistical support in the field, particularly to Carlos (Papi) Armería and to Tania (Torcy)
González for addressing reef size. This work was conceived and carried out by the Reef and Biodiversity Laboratory (ARBIOLAB) in collaboration with the Coastal Ecosystem Laboratory. The work was carried out with funds from the Universidad Autónoma Metropolitana and CONACYT (236654) granted to ALP and LGCB. We thank four anonymous reviewers and editor for commenting and improving the manuscript.

\section{RESUMEN}

\section{Hábitos alimenticios de Holothuria (Stauropora) fuscocinerea (Echinodermata: Holothuroidea) en un arrecife del Pacífico Mexicano}

Introducción: La relevancia de los holoturoideos en los ecosistemas marinos está relacionada con sus actividades alimenticias, las cuales han sido escasamente estudiadas en el Pacífico oriental. Objetivo: Describir los hábitos alimenticios del pepino de mar Holothuria (Stauropora) fuscocinerea y su potencial de bioturbación en el arrecife La Entrega, México. Métodos: Se determinó el tamaño poblacional de H. (Stauropora) fuscocinerea mediante cuatro transectos de banda de 20 × $4 \mathrm{~m}\left(320 \mathrm{~m}^{2}\right)$, mientras que la caracterización de los sedimentos disponibles y las heces de los pepinos se realizó en tres estaciones (A-C) mediante granulometría y cuantificación de carbono orgánico y materia orgánica. Se determinó la tasa de excreción cada $4 \mathrm{hr}$ durante un periodo de $24 \mathrm{hr}$ y se evaluó la relación entre la talla y la biomasa con la tasa de excreción. Resultados: De acuerdo con un análisis no paramétrico mediante permutaciones, ordenación y similitud, las heces de los pepinos estuvieron compuestas en su mayoría por una gran cantidad de granos pequeños en comparación con el sedimento disponible, lo que sugiere que H. (Stauropora) fuscocinerea es una especie selectiva respecto al tamaño de grano. El potencial de bioturbación preliminar de la especie puede alcanzar $8.71 \pm 0.17 \mathrm{~kg}$ día en el área de estudio. Conclusiones: La distribución espacial de $H$. (Stauropora) fuscocinerea en el área de estudio es producto de su selectividad alimenticia, evidenciando la importancia de la especie en la dinámica trófica del arrecife La Entrega.

Palabras clave: selectividad; distribución; alimento; bioturbación; pepino de mar.

\section{REFERENCES}

Amon, R.M.W., \& Herndl, G.J. (1991). Deposit feeding and sediment: I. Interrelationship between Holothuria tubulosa (Holothurioida, Echinodermata) and 
the sediment microbial community. Marine Ecology, 12(2), 163-174.

Anderson, M.J., Gorley, R.N., \& Clarke, K.R. (2008). PERMANOVA+ for PRIMER. Guide to software and statistical methods. Plymouth, UK: PRIMER-E.

Bakus, G.J. (1968). Defensive mechanisms and ecology of some tropical holothurians. Marine Biology, 2, 23-32.

Bakus, G.J. (1973). The biology and ecology of tropical holothurians. In O.A. Jones \& R. Endean (Eds.), Biology and Geology of Coral Reefs (Vol. 2, pp. 325367). New York, USA: Academic Press.

Barrientos-Lujan, N.A., López-Pérez, A., Ríos-Jara, E., Ahumada-Sempoal, M.A., Ortiz, M., \& RodríguezZaragoza, F.A. (2019). Ecological and functional diversity of gastropods associated with hermatypic corals of the Mexican tropical Pacific. Marine Biodiversity, 49, 193-205.

Belbachir, N., Mezali, K., \& Soualili, D.L. (2014). Selective feeding behaviour in some aspidochirotid holothurians (Echinodermata: Holothuroidea) at Stidia, Mostaganem Province, Algeria. SPC Bêche-de-mer Information Bulletin, 34, 34-37.

Benítez-Villalobos, F., Avila-Poveda, O.H., \& Gutiérrez-Méndez, I.S. (2013). Reproductive biology of Holothuria fuscocinerea (Echinodermata: Holothuroidea) from Oaxaca, Mexico. Sexuality and Early Development in Aquatic Organisms, 1, 13-24.

Berthois, L., Crosnier, A., \& Le Calvez, Y. (1968). Contribution à l'étude sédimentologique du plateau continental dans la baie de Biafra. Cahier ORSTOM, $6(3-4), 55-86$.

Billett, D.S.M., Llewellyn, C., \& Watson, J. (1988). Are deep-sea holothurians selective feeders? In R.D. Burke, P.V. Mladenov, P. Lambert \& R.L. Parsley (Eds.), Echinoderm biology (pp. 421-429). Rotterdam: A. Balkema Publishers.

Bonham, K., \& Held, E.E. (1963). Ecological observations on the sea Cucumbers Holothuria atra and H. leucospilota at Rongelap Atoll, Marshall Islands. Pacific Science, 17, 305-314.

Bucol, L.A., Cadivida, A.A., \& Wagey, B.T. (2018) Sediment removal activities of the sea cucumbers Pearsonothuria graeffei and Actinopyga echinites in Tambisan, Siquijor Island, Central Philippines. Jurnal Pesisir dan Laut Tropis, 1(1), 1-7.

Cabral-Tena, R.A., López-Pérez, A., Alvarez-Filip, L., González-Barrios, F.J., Calderón-Aguilera, L.E., \& Aparicio-Cid, C. (2020). Functional potential of coral assemblages along a typical Eastern Tropical Pacific reef tract. Ecological Indicators, 119, 106795.
Calva-Benítez, L.G. (2002). Hábitos alimenticios de algunos equinodermos. Parte 2. Erizos de mar y pepinos de Mar. ContactoS 3 $3^{a}, 47,54-63$.

Cortés, J., Enochs, I.C., Sibaja-Cordero J., Hernández, L., Alvarado, J.J., Breedy, O., . . . Zapata, F.A. (2017). Marine biodiversity of Eastern tropical Pacific coral reefs. In P. Glynn, D. Manzello \& I. Enochs (Eds.), Coral reefs of the Eastern tropical Pacific (Vol. 8, pp. 203-250). Dordrecht, The Netherlands: Springer.

Coulon, P., \& Jangoux, M. (1993). Feeding rate and sediment reworking by the holothuroid Holothuria tubulosa (Echinodermata) in a Mediterranean seagrass bed off Ischia Island, Italy. Marine Ecology Progress Series, 92, 201-204.

Crozier, W.J. (1918). The amount of bottom material ingested by holothurians (Stichopus). Journal of Experimental Zoology, 26(2), 379-389.

Díaz-Díaz, A.D. (2017). Sedimentación en arrecifes coralinos del corredor Puerto Ángel-Bahías de Huatulco, Oaxaca, México (Bachelor thesis). Universidad del Mar, México.

Ebert, T.A. (2021). Problems and puzzles in echinoderm demography. Revista de Biología Tropical, 69(S1), 1-13. DOI 10.15517/rbt.v69iSuppl.1.46318

Emiroglu, D.I., \& Günay, D. (2007). The effect of sea cucumber Holothuria tubulosa (G., 1788) on nutrient and sediment of Aegean Sea shores. Pakistan Journal of Biological Sciences, 10(4), 586-589.

Estrada-Vargas, L. (2008). Determinación de metales pesados en agua, sedimento y coral (Pocillopora damicornis) en Bahías de Huatulco, Oaxaca (Master thesis). Universidad del Mar, México.

FONATUR. (2008). Libro blanco. Relanzamiento del CIP Huatulco. México: Fondo Nacional de Fomento al Turismo.

Gaudette, H.E., Flight, W.R., Toner, L., \& Folger, D.W. (1974). An inexpensive titration method for the determination of organic carbon in recent sediments. Journal of Sedimentary Research, 44(1), 249-253.

Glynn, P.W. (1965). Active movements and other aspects of the biology of Astichopus and Leptosynapta (Holothuroidea). The Biological Bulletin, 129(1), 106-127.

Glynn, P.W. \& Leyte-Morales, G.E. (1997). Coral reefs of Huatulco, west México: Reef development in upwelling Gulf of Tehuantepec. Revista de Biologia Tropical, 45(3), 1033-1047.

Goldberg, W.M. (2013). The biology of reefs and reef organisms. Chicago, USA: University of Chicago Press.

Granja-Fernández, M.R., \& López-Pérez, R.A. (2008). Sedimentación en comunidades arrecifales de Bahías 
de Huatulco, Oaxaca, México. Revista de Biología Tropical, 56(3), 1179-1187.

Grybos, M., Davranche, M., Gruau, G., \& Petitjean, P. (2007). Is trace metal release in wetland soils controlled by organic matter mobility or Fe-oxyhydroxides reduction? Journal of Colloid and Interface Science, 314(2), 490-501.

Hammond, L.S. (1982). Patterns of feeding and activity in deposit-feeding holothurians and echinoids (Echinodermata) from a shallow back-reef lagoon, Discovery Bay, Jamaica. Bulletin of Marine Science, 32(2), 549-571.

Hammond, L.S. (1983). Nutrition of deposit-feeding holothuroids and echinoids (Echinodermata) from a shallow reef lagoon, Discovery Bay, Jamaica. Marine Ecology Progress Series, 10, 297-305.

Hendler, G., Miller, J.E., Pawson, D.L., \& Kier, P.M. (1995). Sea stars, sea urchins, and allies: Echinoderms of Florida and the Caribbean. Washington, London: Smithsonian Institute Press.

Herrero-Pérezrul, M.D., \& Chávez, E.A. (2005). Optimum fishing strategies for Isostichopus fuscus (Echinodermata: Holothuroidea) in the Gulf of California, Mexico. Revista de Biología Tropical, 53(3), 357-366.

Longbottom, M.R. (1970). The distribution of Arenicola marina (L.) with particular reference to the effects of particle size and organic matter of the sediments. Journal of Experimental Marine Biology and Ecology, 5(2), 138-157.

López-Pérez, R.A., \& Hernández-Ballesteros, L.M. (2004). Coral community structure and dynamics in the Huatulco area, western Mexico. Bulletin of Marine Science, 75(3), 453-472.

López-Pérez, R.A., \& López-García, A. (2008). Identification of priority conservation sites for reef building corals in Oaxaca state, Mexico. Hidrobiológica, 18(3), 239-249.

López-Pérez, A., Granja-Fernández, R., Valencia-Méndez, O., Aparicio-Cid, C., Torres-Huerta, A.M., Barrientos-Lujan, N.A., . . Hernández, L. (2019). Biodiversity associated with southern Mexican Pacific corals. In A.L. Ibáñez (Ed.), Mexican aquatic environments (pp. 119-114). Switzerland: Springer.

Luna-Salguero, B.M., \& Reyes-Bonilla, H. (2010). Community and trophic structure of sea stars (Echinodermata: Asteroidea) in rocky reefs of Loreto, Gulf of California, Mexico. Hidrobiológica, 20(2), 127-34.

Massin, C. (1979). The sediment ingested by Holothuria tubulosa Gmel (Holothuroidea: Echinodermata). In M. Jangoux (Ed.), Proceedings of the 2nd European Colloquium on Echinoderms (pp. 205-208). Rotterdam: A. Balkema Publishers.
Massin, C., \& Jangoux, M. (1976). Observations écologiques sur Holothuria tubulosa, H. poli et H. forskali (Echinodermata, Holothuroidea) et comportement alimentaire de $H$. tubulosa. Cahiers de Biologie Marine, 17, 45-59.

Mercier, A., Battaglene, S.C., \& Hamel, J.F. (1999). Daily burrowing cycle and feeding activity of juvenile sea cucumbers Holothuria scabra in response to environmental factors. Journal of Experimental Marine Biology and Ecology, 239(1), 125-156.

Mezali, K., \& Soualili, D.L. (2013). The ability of holothurians to select sediment particles and organic matter. SPC Beche-de-Mer Information Bulletin, 33, 38-43.

Michio, K., Kengo, K., Yasunori, K., Hitoshi, M., Takayuki, Y., Hideaki, Y., \& Hiroshi, S. (2003). Effects of deposit feeder Stichopus japonicus on algal bloom and organic matter contents of bottom sediments of the enclosed sea. Marine Pollution Bulletin, 47, 118-125.

Poppe, J.L., Knebel, H.J., Mlodzinska, Z.J., Hastings, M.E., \& Seekins, B.A. (2000). Distribution of surficial sediment in Long Island Sound and adjacent waters: texture and total organic carbon. Journal of Coastal Research, 16(3), 567-574.

Purcell, S.W., Samyn, Y., \& Conand, C. (2012). Commercially important sea cucumbers of the world. Rome, Italy: FAO Species Catalogue for Fishery Purposes No. 6.

Purcell, S.W., Conand, C., Uthicke, S., \& Byrne, M. (2016). Ecological roles of exploited sea cucumbers. Oceanography and Marine Biology: An Annual Review, 54, 367-386.

Rioja, R.A., Palomar-Abesamis, N., \& Juinio-Meñez, M.A. (2020). Development of nocturnal feeding and photosensitivity in early juveniles of the warty sea cucumber Stichopus cf. horrens. Behavioural Processes, 178, 104181.

Ruiz, J.F., Ibánez, C.M., \& Cáceres, C.W. (2007). Morfometría del tubo digestivo y alimentación del pepino de mar Athyonidium chilensis (Semper, 1868) (Echinodermata: Holothuroidea). Revista de Biología Marina y Oceanografia, 42(3), 269-274.

SEMARNAT. (2019). Modificación del Anexo Normativo III, Lista de especies en riesgo de la Norma Oficial Mexicana NOM-059-SEMARNAT-2010, Protección ambiental-Especies nativas de México de flora y fauna silvestres-Categorías de riesgo y especificaciones para su inclusión, exclusión o cambio-Lista de especies en riesgo. Ciudad de México, México: SEGOB.

Sheppard, C.R.C., Davy, S.K., Pilling, G.M., \& Graham, N.A.J. (2017). The biology of coral reefs. Oxford, UK: Oxford University Press. 
Shoham-Frider, E., Gertner, Y., Guy-Haim, T., Herut, B., Kress, N., Shefer, E., \& Silverman, J. (2020). Legacy groundwater pollution as a source of mercury enrichment in marine food web, Haifa Bay, Israel. Science of the Total Environment, 714, 1-34.

Slater, M.J., \& Carton, A.G. (2009). Effect of sea cucumber (Australostichopus mollis) grazing on coastal sediments impacted by mussel farm deposition. Marine Pollution Bulletin, 58(8), 1123-1129.

Solís-Marín, F.A., Alvarado, J.J., Abreu-Pérez, M., Aguilera, O., Alió, J., Bacallado-Aránega, J.J., . . . Williams, S.M. (2013). Appendix. In J.J. Alvarado-Barrientos \& F.A. Solís-Marín (Eds.), Echinoderm research and diversity in Latin America (pp. 543-658). Berlin: Springer Heidelberg.

StatSoft, Inc. (2020). STATISTICA (data analysis software system) (Version 7.1) Retrieved from https://www. jmp.com/en us/download-jmp-free-trial.html.

Taghon, G.L., Self, R.F., \& Jumars, P.A. (1978). Predicting particle selection by deposit feeders: A model and its implications. Limnology and Oceanography, 23(4), $752-759$.

Thayer, C.W. (1983). Sediment-mediated biological disturbance and the evolution of marine benthos. In M.J.S. Tevesz \& P.L. McCall (Eds.), Biotic interactions in recent and fossil benthic communities. Topics in geobiology (Vol. 3, pp. 479-625). Boston, USA: Springer.

Trefz, S.M. (1956). Observations on the anatomy, both macroscopical and microscopical, of the intestinal tract and of accompanying organs and on the physiology of digestion in Holothuria atra (Jager) with additional observations on the ecology of Holothurians and their possible role in the destruction of coral reefs. Honolulu, Hawaii: Hawaii University Honolulu.
Uthicke, S. (1994). Distribution patterns and growth of two reef flat holothurians, Holothuria atra and Stichopus chloronotus. In B. David, A. Guille, J.P. Féral \& M. Roux (Eds.), Echinoderms (Dijon), Proceedings of the 8th International Echinoderm Conference (pp. 569-576). Rotterdam: A. Balkema Publishers.

Uthicke, S. (1999). Sediment bioturbation and impact of feeding activity of Holothuria (Halodeima) atra and Stichopus chloronotus, two sediment feeding holothurians, at Lizard Island, Great Barrier Reef. Bulletin of Marine Science, 64(1), 129-141.

Yamanouchi, T. (1939). Ecological and physiological studies on the holothurians in the coral reef of Palao Islands. Palao Tropical Biological Station Studies, 4, 603-634.

Yamanouchi, T. (1956). The daily activity rhythms of the holothurians in the coral reef of Palao Islands. Publications of the Seto Marine Biological Laboratory, 3(5), 347-362.

Yang, H., Yuan, X., Zhou, Y., Mao, Y., Zhang, T., \& Liu, Y. (2005). Effects of body size and water temperature on food consumption and growth in the sea cucumber Apostichopus japonicus (Selenka) with special reference to aestivation. Aquaculture Research, 36, 1085-1092.

Yuan, X., Yang, H., Zhou, Y., Mao, Y., Zhang, T., \& Liu, Y. (2006). The influence of diets containing dried bivalve faeces and/or powdered algae on growth and energy distribution in sea cucumber Apostichopus japonicus (Selenka) (Echinodermata: Holothuroidea). Aquaculture, 256(1-4), 457-467.

Zhou, Y., Yang, H., Liu, S., Yuan, X., Mao, Y., Liu, Y., ... Zhang, F. (2006). Feeding and growth on bivalve biodeposits by the deposit feeder Stichopus japonicus Selenka (Echinodermata: Holothuroidea) co-cultured in lantern nets. Aquaculture, 256(1-4), 510-520. 